\title{
Involvement of Reactive Oxygen Intermediates in Cyclooxygenase-2 Expression Induced by Interleukin-1, Tumor Necrosis Factor- $\alpha$, and Lipopolysaccharide
}

\author{
Lili Feng, * Yiyang Xia, * Gabriela E. Garcia, ${ }^{*}$ Daniel Hwang, ${ }^{\star}$ and Curtis B. Wilson * \\ ${ }^{*}$ Department of Immunology, The Scripps Research Institute, La Jolla, California 92037; and ${ }^{\ddagger}$ Pennington Biomedical Research Center, \\ Louisiana State University, Baton Rouge, Louisiana 70808
}

\begin{abstract}
Reactive oxygen intermediates (ROIs) play an important role in inflammatory processes as mediators of injury and potentially in signal transduction leading to gene expression. Cyclooxygenase (COX) is a rate-limiting enzyme in prostanoid biosynthesis, and its recently cloned inducible form, COX-2, is induced by proinflammatory cytokines. This study linked ROIs to the signaling pathways that induce COX-2 expression. The hydroxyl radical scavengers DMSO (1\%), as well as di- and tetramethylthiourea, inhibited IL1 - , TNF $\alpha$-, and LPS-induced COX-2 expression in rat mesangial cells. The suppression of COX-2 mRNA expression correlated with the COX-2 protein level. In comparison with the prolonged induction of the inducible gene encoding protein-tyrosine phosphatase by hydrogen peroxide, the COX2 gene was only transiently induced. Protein-tyrosine phosphatase is also induced by heat shock and chemical stress, whereas COX-2 is not. Superoxide was a more potent inducer for COX-2 than hydrogen peroxide. In addition, NADPH stimulated COX-2 expression, and an inhibitor of NADPH oxidase blocked COX-2 expression induced by TNF $\alpha$. COX-2 and KC gene expression costimulated by IL1 were inhibited differentially by the scavengers. These studies demonstrate that oxidant stress is a specific and important inducer of COX-2 gene expression. This induction may contribute to the deleterious amplification of prostanoids in inflammation and compound the direct effects of ROI production. (J. Clin. Invest. 1995. 95:1669-1675.) Key words: reactive oxygen intermediates - NADPH - mesangial cell • PTPase $・$ KC
\end{abstract}

\section{Introduction}

Cyclooxygenase $(\mathrm{COX})^{1}$ is a rate-limiting enzyme in prostanoid synthesis. COX-2 is a recently cloned form of COX that is

Address correspondence to Curtis B. Wilson, M.D., Department of Immunology (IMM 5), The Scripps Research Institute, 10666 North Torrey Pines Road, La Jolla, CA 92037.

Received for publication 20 June 1994 and in revised form 16 December 1994.

1. Abbreviations used in this paper: $\mathrm{CHX}$, cycloheximide; COX, cyclooxygenase; DMTU, dimethylthiourea; GAPDH, glyceraldehyde3-phosphate dehydrogenase; HMAP, 4'-hydroxy-3' methyl-acetophenone; PTPase, protein-tyrosine phosphatase; ROI, reactive oxygen intermediate; TMTU, tetramethylthiourea.

J. Clin. Invest.

(C) The American Society for Clinical Investigation, Inc.

$0021-9738 / 95 / 04 / 1669 / 07 \$ 2.00$

Volume 95, April 1995, 1669-1675 induced in a number of cells by proinflammatory stimuli (15 ). Exposure of a variety of cells or tissues, including rat mesangial cells, to IL-1, TNF $\alpha$, or LPS results in increased levels of mRNA and peptide for COX-2, but not for COX-1 (6-9). We have recently cloned rat COX-1 and COX-2 and studied the regulation of both genes (10); however, the second messengers involved in the signal transduction pathways leading to induction of COX-2 remain incompletely defined. Hydrogen peroxide can stimulate prostaglandin production in vivo (11). Inhibitors of reactive oxygen formation and the scavengers of reactive oxygen species have been reported to block prostanoid production by quenching the generation of hydroperoxides, which are activators of COX (12). Reactive oxygen intermediates (ROIs) are agents commonly produced by inflammatory cells during inflammatory processes (13), including those occurring in arthritis and glomerulonephritis. In the latter, glomerular cells, particularly mesangial cells, can generate ROIs independently of infiltrating cells, which may serve an autacoid role in glomerular injury (14). IL-1 and TNF $\alpha$ induce both superoxide and hydrogen peroxide production in human mesangial cells, with production increasing during a 90-min exposure (15).

To determine whether ROIs are involved in the expression of COX-2 induced by IL- 1 , TNF $\alpha$, and LPS, the effects of the radical scavengers DMSO and di- and tetramethylthiourea (DMTU and TMTU) and of other antioxidants on the expression of COX-2 were compared with those on COX-1 and the rat homolog of a known oxidant-inducible protein, tyrosine phosphatase (PTPase, CL100/3CH134) $(16,17)$. To show the specificity of ROIs in COX-2 expression, the effects of the radical scavengers on the expression of the rat $\mathrm{KC}$ gene, a chemokine also induced by IL-1 (18), were compared with their effects on COX-2. Membrane-bound NADPH-dependent oxidase components have been identified on human mesangial cells and have been suggested as a source for generation of ROIs by mesangial cells $(19,20)$. To study the role of NADPH, both NADPH stimulation and inhibition were used.

\section{Methods}

Culture of rat mesangial cells. Rat mesangial cells were a gift from Dr. Jeffrey I. Kreisberg (Department of Pathology, University of Texas Health Science Center at San Antonio, San Antonio, TX). Mesangial cells were identified by ultrastructural, biochemical, and immunofluorescence techniques (21). Cells were cultured in RPMI 1640 tissue culture medium containing $20 \%$ FCS with antibiotics and an antimycotic. All experiments were performed on $80 \%$ confluent cells between the 8 th and 12th passages.

Reverse transcriptase PCR cloning of rat PTPase (CL100/3CH134)

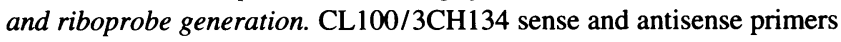
were designed by alignment of human ( $\mathrm{CL} 100)$ and murine (3CH134) (16, 17), 5'-GGATCCGAAGCTGTTTTCGGCTTCCTGC-3' with BamHI site at the 5' end; and 5'-CTTGTACTGGTAGTGACCCTC-3' 
for antisense. In vivo excised DNA from an LPS-stimulated rat peritoneal macrophage cDNA library constructed in XZapII (a gift of Dr. Wolfgang Northemann, The Scripps Research Institute) was used as a template to clone a PTPase 298-bp cDNA fragment (from 376 to 664 bp of the mouse homolog). PCR was performed for 30 cycles with denaturing at $93^{\circ} \mathrm{C}$ for $30 \mathrm{~s}$, annealing at $60^{\circ} \mathrm{C}$ for $40 \mathrm{~s}$, and elongating at $72^{\circ} \mathrm{C}$ for $30 \mathrm{~s}$. The PCR products were digested with BamHI and subcloned in pBluescript (Stratagene, La Jolla, CA) digested with BamHI and EcoRV. This probe was used to screen the rat peritoneal macrophage cDNA library. Several full-length clones were obtained (Feng, L., Y. Xia, D. Seiffert, and C. B. Wilson, manuscript in preparation). The cDNAs were sequenced with an automated DNA sequencer (ABI 373A; Applied Biosystems, Foster City, CA) using appropriate primers. A 177-bp Ncol fragment of rat PTPase (114-291) was subcloned into pGEM5Z (Promega Corp., Madison, WI), and the clone with the $3^{\prime}$ end toward the $T_{7}$ promoter was selected. The recombinant plasmid was linearized with EcoRV and transcribed using $T_{7}$ polymerase. A 132-bp rat $\mathrm{KC}$ fragment was subcloned from rat $\mathrm{KC}$ by digesting cDNA with PstI and NcoI and was then ligated into pGEM5Z. The recombinant plasmid was linearized with SalI and transcribed with $T_{7}$ RNA polymerase. The 340-bp rat COX-1, 242-bp rat COX-2, and 114bp rat glyceraldehyde-3-phosphate dehydrogenase (GAPDH), termed GAP 114 , probes have been described previously $(10,22)$.

Total RNA extract and RNase protection assay. The total RNA was prepared by a single-step method (23), quantitated by its absorption at $260 \mathrm{~nm}$, and frozen at $-70^{\circ} \mathrm{C}$. $1 \mu \mathrm{g}$ of total RNA was hybridized with $10^{5} \mathrm{cpm}$ of each ${ }^{32} \mathrm{P}$-labeled rat antisense riboprobe. The RNase protection assay was performed as described previously, and the radioactivity in the protected bands was quantitated by the Radioanalytic Imaging System (AMBIS Systems, San Diego, CA) $(10,22)$.

Western blot determination of total enzyme protein levels. The level of COX-2 was analyzed by Western blot analysis using an anti-COX2 antibody as described previously (10). Briefly, cells were sonicated in PBS, pH 7.4, containing $10 \mathrm{mM}$ EDTA, $5 \mathrm{mM}$ EGTA, $1 \mathrm{mM}$ PMSF, and $10 \mu \mathrm{M}$ leupeptin for $30 \mathrm{~s}$. Microsomes from the lysed cells were electrophoresed on an 8\% SDS-polyacrylamide gel and were transblotted onto a nitrocellulose filter. The blot was blocked with $5 \%$ nonfat milk, incubated in the antibody solution (diluted 1:250) overnight, and treated with goat anti-rabbit IgG conjugated with alkaline phosphatase (diluted 1:1,500). Color development was done with alkaline phosphatase color reagents (Boehringer Mannheim, Indianapolis, IN).

Nuclear run-off transcription assay. Nuclear run-off analysis was performed as described previously (18). Briefly, nuclei were prepared by lysing $10^{8}$ cells in a buffer $(10 \mathrm{mM}$ Tris- $\mathrm{HCl}, \mathrm{pH} 7.4,3 \mathrm{mM} \mathrm{CaCl}$, $2 \mathrm{mM} \mathrm{MgCl}_{2}$ ) containing $0.6 \%$ NP- 40 . Nuclei were collected by centrifugation, placed in a storage buffer $(50 \mathrm{mM}$ Tris- $\mathrm{HCl}, \mathrm{pH} 8.3,40 \%$ glycerol, $5 \mathrm{mM} \mathrm{MgCl} 2,0.1 \mathrm{mM}$ EDTA), and held at $-80^{\circ} \mathrm{C}$. Upon thawing, nuclei were resuspended and incubated with an equal volume of labeling buffer ( $300 \mathrm{mM} \mathrm{KCl}, 0.5 \mathrm{mM}$ each ATP, GTP, and CTP), containing $200 \mu \mathrm{Ci}$ of $\left[\alpha{ }^{32} \mathrm{P}\right]$ UTP (DuPont-NEN, Boston, MA) at $30^{\circ} \mathrm{C}$ for $1 \mathrm{~h}$. After pulse labeling, radiolabeled RNA was prepared by sequential DNase I digestion, organic extraction, ethanol precipitation, and TCA precipitation. For probing, plasmids containing full-length COX-1, COX-2, PTPase, or GAP 114 cDNA (10 $\mu \mathrm{g}$ per dot) were blotted onto membranes using a slot-blot apparatus (Schleicher \& Schuell, Keene, NH) and hybridized for $48 \mathrm{~h}$ at $65^{\circ} \mathrm{C}$ with pulse-labeled RNA. After washing at high stringency, the membranes were exposed to $\mathrm{x}$-ray film at $-70^{\circ} \mathrm{C}$ for $5 \mathrm{~d}$. After autoradiography, the quantities of the transcript were determined by scanning the $x$-ray film with a densitometer, and the final values were factored by the GAP 114 mRNA.

Prostaglandin $E_{2}$ assay. To determine COX activity, cell supernatants were assayed for prostaglandin $\mathrm{E}_{2}\left(\mathrm{PGE}_{2}\right)$ using previously published methods (10).

\section{Results}

Radical scavengers suppress COX-2 expression induced by IL$1, T N F \alpha$, and LPS. Rat mesangial cells stimulated by proin- flammatory cytokines and LPS express both COX-2 and PTPase, but not COX-1 (Fig. $1 A$ ). All three of the hydroxyl radical scavengers, DMSO, DMTU, and TMTU, reduced the expression of COX-2 and PTPase in cytokine-stimulated mesangial cells at $4 \mathrm{~h}$ without affecting levels of COX-1 or the housekeeping gene GAPDH (Fig. $1 A$ ). DMTU and TMTU, at a dose of $10 \mathrm{mM}$, almost completely blocked steady-state COX2 mRNA induced at $4 \mathrm{~h}$ by all three stimuli (IL-1, TNF $\alpha$, and LPS), whereas equimolar urea as a control had no effect on the expression of COX-2 and PTPase. In contrast to DMTU and TMTU, DMSO, which inhibited TNF $\alpha$-induced COX-2 expression, only partially inhibited IL-1-induced COX-2 expression (55\%) and had no effect on LPS-induced COX-2 expression. DMSO also was relatively ineffective in reducing the induced PTPase mRNA levels. The decrease in COX-2 steadystate mRNA levels was mirrored by a decrease in COX activity, as assessed by $\mathrm{PGE}_{2}$ production (Fig. $1 \mathrm{~B}$ ).

To examine the possible role of protein synthesis in the DMTU inhibition of IL-1-induced COX-2 expression, a study was done using cycloheximide (CHX). IL-1 with or without DMTU was used to stimulate mesangial cells in the presence or absence of $25 \mu \mathrm{g} / \mathrm{ml} \mathrm{CHX}$. Using the ratios of (COX-2/ GAPDH counts per minute ) $\times 10$ as determined by the AMBIS system, readout values of $0.06,0.92,0.62,1.16,0.10$, and 0.12 were found for control, IL-1 alone, CHX alone, IL-1 + CHX, IL-1 + DMTU, and IL-1 + DMTU + CHX, respectively. This indicated that COX-2 expression was superinduced by IL- 1 in the presence of CHX. It also showed that the DMTU inhibition of IL-1-induced COX-2 expression was not changed by $\mathrm{CHX}$, indicating that protein synthesis was not required for the inhibitory effect.

DMTU suppresses COX-2 induction by IL-1 in a dose- and time-dependent manner. As shown in Fig. $2 \mathrm{~A}$, the addition of DMTU suppressed the COX-2 expression in a dose-dependent fashion at $4 \mathrm{~h}$. DMTU at $1 \mathrm{mM}$ inhibited COX-2 expression to $40 \%$, and nearly complete suppression was observed at $10 \mathrm{mM}$. In the time course study, when DMTU (10 mM) was incubated concurrently with IL- 1 a mean suppression ( $n=3$ studies) of COX-2 steady-state mRNA levels of $20,56,93$, and $83 \%$ was found at $1,2,4$, and $8 \mathrm{~h}$, respectively. The COX-2 protein level (Fig. $2 B$ ) correlated well with the COX-2 mRNA level.

Effects of DMTU and TMTU on mRNA levels for COX-2 and PTPase induced by serum or PMA. In addition to proinflammatory cytokines, serum and PMA are strong inducers of COX-2. As previously described, the later stage $(2-4 \mathrm{~h})$ induction of COX- 2 gene expression by LPS, TNF $\alpha$, and IL- $1 \alpha$ is oxidant dependent. We examined whether ROIs might be involved in the intracellular signaling after serum induction of COX-2. As shown in Fig. 3, DMTU and TMTU had no effect on serum-induced COX-2 expression and incompletely suppressed PMA-induced COX-2 expression, suggesting that the signaling involved in serum induction is different from that of the proinflammatory cytokines. The scavengers had no effect on the PTPase mRNA induced by PMA, again suggesting different regulatory mechanisms for COX-2 and PTPase.

Selectivity of scavenger effects using $K C$ expression induced by $I L-1$. To verify further the specificity of the scavenger effect on oxidant stress genes, the effect of the scavengers on another IL-1-inducible gene, KC, was studied. As shown in Fig. 4, KC was strongly induced by IL-1; however, the scavengers had no effect on KC expression. Both COX-2 and PTPase expression were dramatically inhibited, as expected. 
A
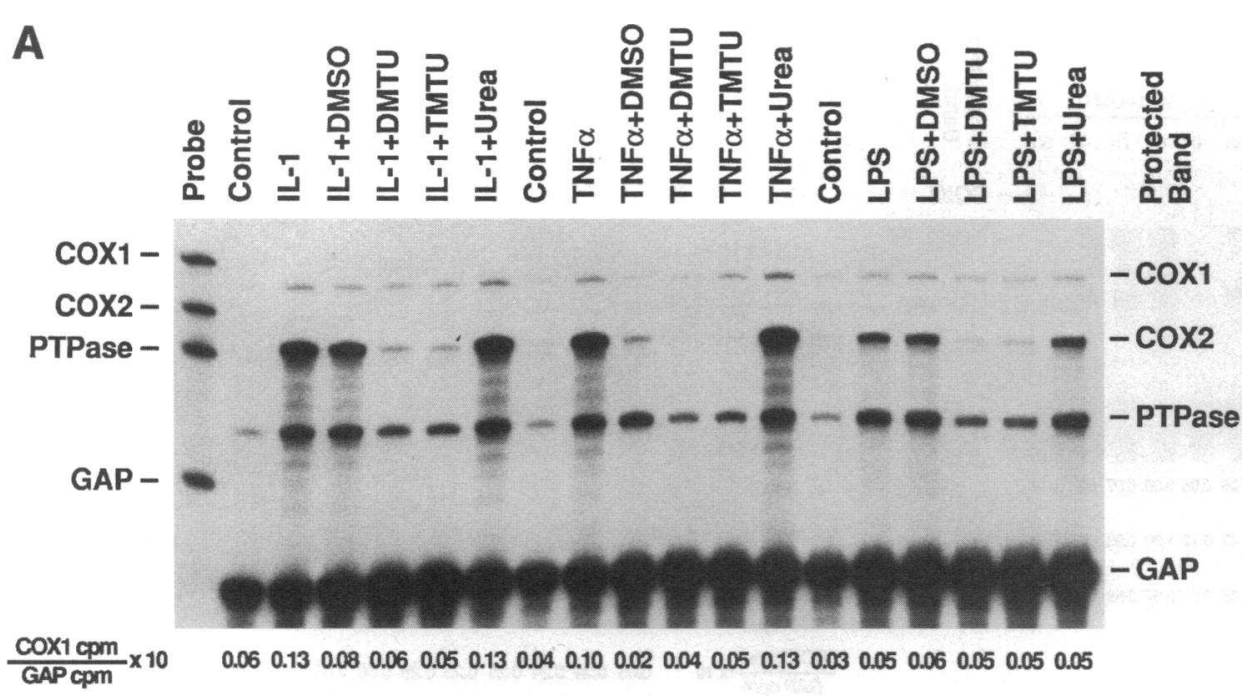

Figure 1. (A) RNase protection assay analysis of mRNA for COX-1, COX2, PTPase, and GAPDH in mesangial cells. After attaining confluency, mesangial cells were incubated in serumfree RPMI 1640 for $48 \mathrm{~h}$ and were then further incubated in the serumfree medium with various reagents for $4 \mathrm{~h}$ before harvesting. The cells were treated in the presence of IL-1 (1 ng/ $\mathrm{ml}), \mathrm{TNF} \alpha(200 \mathrm{U} / \mathrm{ml})$, or LPS (1 $\mu \mathrm{g} / \mathrm{ml})$ with or without DMSO ( $1 \%)$, DMTU (10 mM), TMTU (10 mM), or urea $(10 \mathrm{mM})$ for $4 \mathrm{~h}$. The protected COX-1, COX-2, PTPase, and GAPDH bands are shorter than their respective probes because the unhybridized polylinker regions in the cRNA probes are digested by RNase. The counts per minute of the bands in each lane were factored for GAPDH counts, and the ratio of the two values $\times 10$ is presented below each lane. $(B) 4 \mathrm{~h}$ after the treatment indicated, the mesangial cell supernatants were collected and assayed for $\mathrm{PGE}_{2}$. The final values were factored relative to protein level (in milligrams) assayed by the Bradford method. Each point represents mean $\pm \operatorname{SE}(n=3)$.

Induction of $\mathrm{COX}-2$ expression with hydrogen peroxide and superoxide. To determine whether ROIs could directly induce expression of COX-2 in mesangial cells, the cells were incubated with hydrogen peroxide or a superoxide-generating system. The time course for hydrogen peroxide COX-2 induction is shown in Fig. 5. Hydrogen peroxide transiently induced a low level of COX-2 expression that increased at $1 \mathrm{~h}$, peaked at $4 \mathrm{~h}$, and declined thereafter. The time course of ROI-induced COX-2 expression corresponded to the time course of ROI scavenger inhibition of cytokine-induced COX-2 expression. In comparison with COX-2, PTPase was dramatically induced by hydrogen peroxide, with the induction occurring as early as 15 min and lasting for $12 \mathrm{~h}$. COX-2 was markedly induced by superoxide generated by xanthine oxidase hypoxanthine and the superoxide-generated drug menadione.

Induction of COX-2 expression by ROIs generated by NADPH-dependent oxidase. The generation of ROIs by mesangial cells has been linked to NADPH-dependent oxidase (19). The effects of NADPH and the inhibitor of NADPH oxidase 4 '-hydroxy-3'-methoxy-acetophenone (HMAP) (19) on COX2 expression by mesangial cells were examined. NADPH added to the incubation medium increased COX-2 expression in a dose-dependent fashion. The COX-2 expression induced by
NADPH was suppressed by DMTU and TMTU (Fig. 6). The NADPH oxidase inhibitor HMAP blocked TNF $\alpha$-induced COX expression and partially blocked IL-1-induced COX-2 expression while having little affect on LPS-, serum-, or PMA-induced COX-2 expression (Fig. 6). This indicated a role for NADPH in intracellular signaling during TNF $\alpha$ - and probably IL-1induced expression of COX-2.

The radical scavenger DMTU transcriptionally inhibits COX-2 mRNA expression. The effects of radical scavengers on the transcription of the COX-2 and PTPase genes were examined by nuclear run-off assay. Mesangial cells were stimulated with IL-1 $(1 \mathrm{ng} / \mathrm{ml})$ for $30 \mathrm{~min}$ or $2 \mathrm{~h}$ in the presence or absence of DMTU. There was a marked increase in both COX-2 and PTPase transcripts after stimulation, and this increase was blocked by DMTU at $2 \mathrm{~h}$, but not at $30 \mathrm{~min}$, corresponding to the findings of the scavenger effect on steady-state COX-2 expression (Fig. 7).

COX-2 and PTPase expression responds differently to environmental stress. COX-2 expression induced by hydrogen peroxide and superoxide might be a response of the mesangial cell to environmental stress. The expression of COX-2 was not induced at $45^{\circ} \mathrm{C}$ in contrast to PTPase, which was strongly induced (Fig. 8). The heat shock induction of PTPase was not 


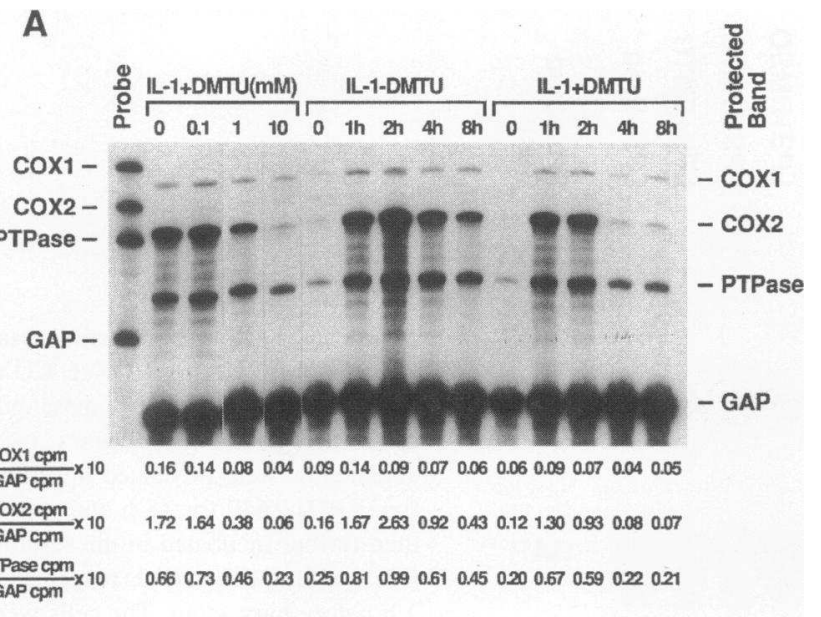

B

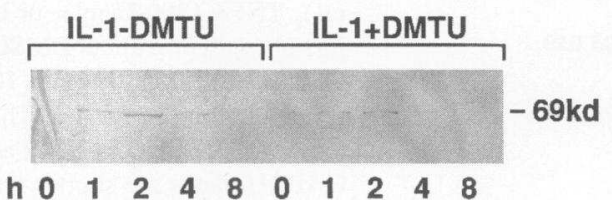

Figure 2. (A) Time- and dose-dependent inhibition of COX-2 expression as assessed by RNase protection assay in mesangial cells stimulated by IL-1. Cells preincubated in serum-free medium for $48 \mathrm{~h}$ were further incubated in medium containing IL-1 $(1 \mathrm{ng} / \mathrm{ml})$ with or without urea or DMTU for the specified times or doses (4-h incubation). Total RNA was extracted and hybridized with riboprobes, as described in Methods. The $\left[\alpha^{-32}\right.$ P]UTP-labeled COX-1, COX-2, PTPase, and GAPDH riboprobes were protected with the complementary mRNA from mesangial cells. The ratio of counts per minute was calculated as described in Fig. 1. (B) Western blot analysis of COX-2 in mesangial cells stimulated by IL-1 with or without DMTU. The mesangial cells were incubated in serum-free RPMI 1640 for $48 \mathrm{~h}$ and were then further incubated in RMPI 1640 with IL-1 $(1 \mathrm{ng} / \mathrm{ml})$ with or without DMTU $(10 \mathrm{mM})$ for the specified times. Western blot analysis was performed as described in Methods.

inhibited by the scavengers. These results indicate that although the induction of COX-2 and PTPase expression can be mediated through an oxidant-dependent mechanism, they are not coordinately induced by other stress treatments.

\section{Discussion}

The hydroxyl radical scavengers DMTU and TMTU, and to a lesser extent DMSO, inhibited the later stages $(2-4 \mathrm{~h})$ of IL-1 -, TNF $\alpha$-, and LPS-induced COX-2 expression without affecting COX-1 or GAPDH mRNA expression. The scavengers were less effective in inhibiting COX-2 expression induced by PMA or serum, and the expression of PTPase induced by PMA was not blocked at all by the scavengers. The differential inhibitory effects of the scavengers on the expression of COX2 and PTPase induced by serum, PMA, cytokines, and LPS implied that the inhibitory effects were specific. By nuclear runoff assay, IL-1 transcriptionally induced COX-2 expression. The scavenger-induced decrease in COX-2 expression was shown to be related to transcriptional inhibition at later time points (2 h), since DMTU decreased transcriptional activity. The delayed transcriptional inhibition correlated with the steady-state COX-

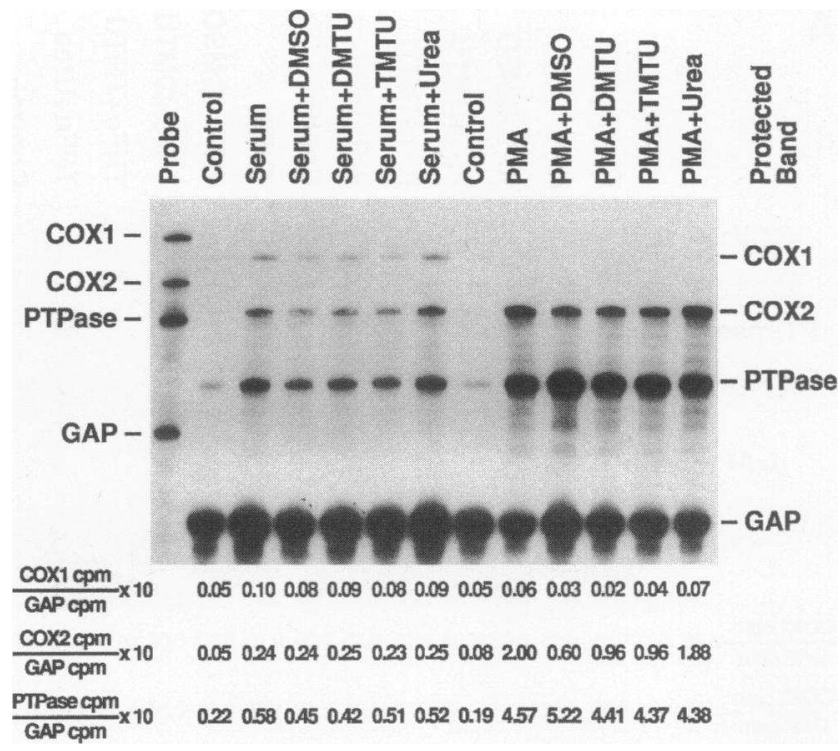

Figure 3. Effects of DMSO ( $1 \%$ ), DMTU ( $10 \mathrm{mM}$ ), TMTU ( $10 \mathrm{mM}$ ), and urea $(10 \mathrm{mM})$ on mRNA levels for COX-1, COX-2, and PTPase induced by serum and PMA, as assessed by RNase protection assay. Cells preincubated in serum-free medium for $48 \mathrm{~h}$ were further incubated in medium containing $10 \%$ FCS or PMA $(200 \mathrm{nM})$. Radioactivity was analyzed by the AMBIS system (see Methods).

2 mRNA level. The transcriptional inhibition of COX-2 resulted in the reduction of COX-2 protein. A decrease in COX activity was also seen in the experiments (Fig. $1 B$ ). Marked inhibition occurred at $4 \mathrm{~h}$. DMTU inhibition of COX-2 mRNA expression

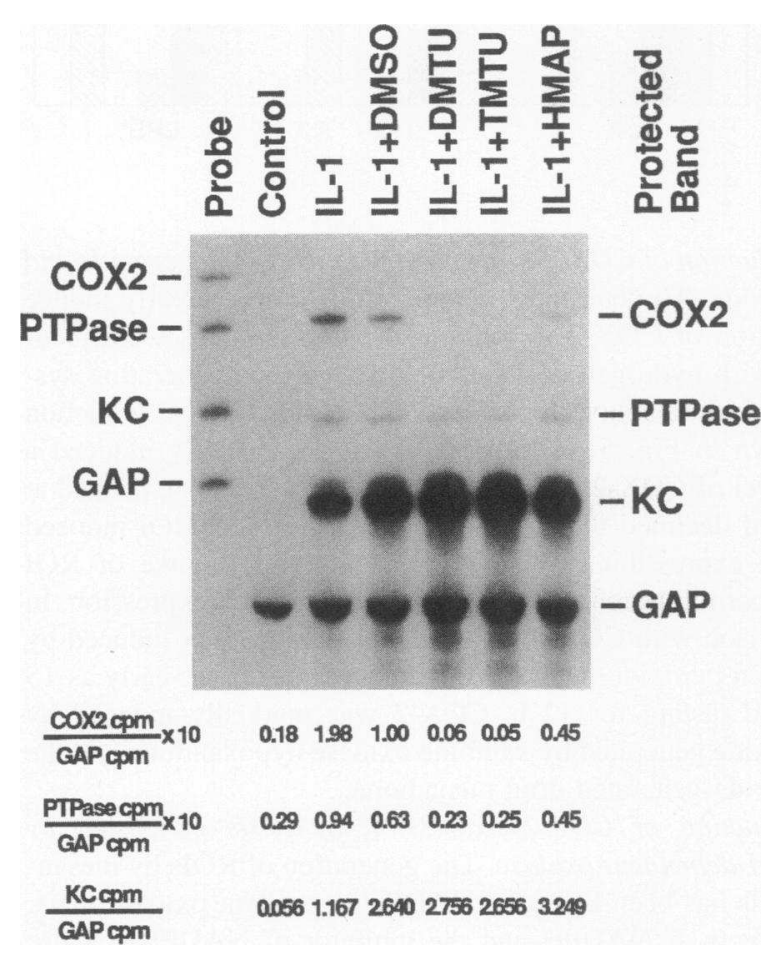

Figure 4. The effects of the scavengers on the mRNA levels for COX2, PTPase, KC, and GAPDH. After serum starvation for $48 \mathrm{~h}$, the cells were incubated in serum-free medium containing IL-1 $(1 \mathrm{ng} / \mathrm{ml})$ with or without DMTU (10 mM) or TMTU (10 mM). 


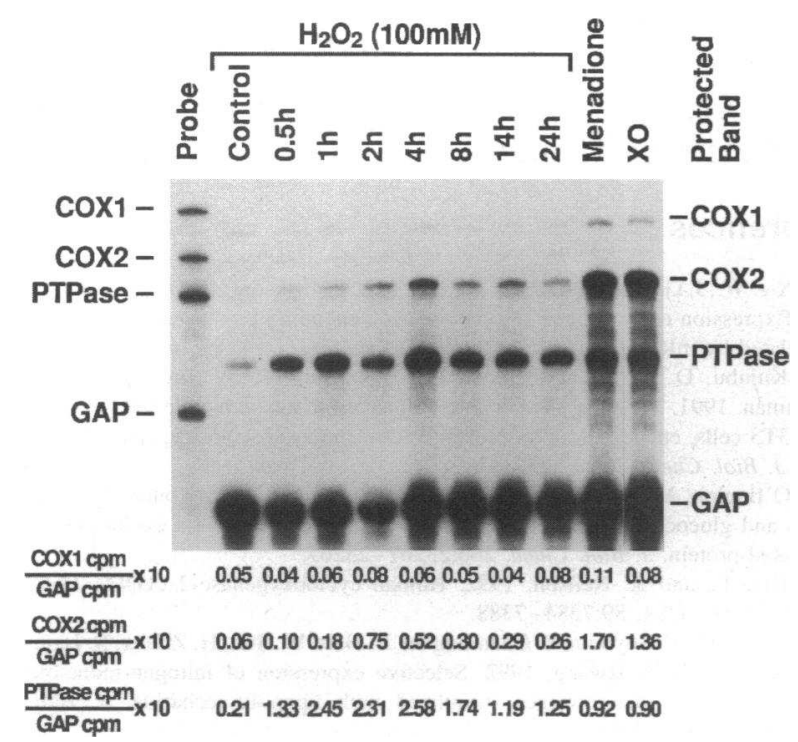

Figure 5. Effects of hydrogen peroxide $(100 \mu \mathrm{M})$, xanthine oxidase $(X O ; 10 \mathrm{mU} / \mathrm{ml}) /$ hypoxanthine $(\mathrm{HX}, 0.6 \mathrm{mM})$, and menadione $(500$ $\mu \mathrm{M}$ ) on the mRNA levels for COX-1, COX-2, and PTPase as assessed by RNase protection assay.

was not affected by CHX, suggesting that ROI-mediated COX2 gene expression induced by IL-1 might belong to the delayed early response (24).

Since neither COX-1 nor GAPDH was stimulated by the proinflammatory agents and PTPase expression also was regulated through the antioxidant-sensitive mechanism, these three genes may not represent adequate controls. Therefore, another IL-1 -inducible gene, $\mathrm{KC}$, was selected as a control. $\mathrm{KC}$ belongs to a large superfamily of chemokines and is regulated by proinflammatory cytokines (18). It was recently reported that IL-8 and MCP-1, members of the chemokine family, are regulated

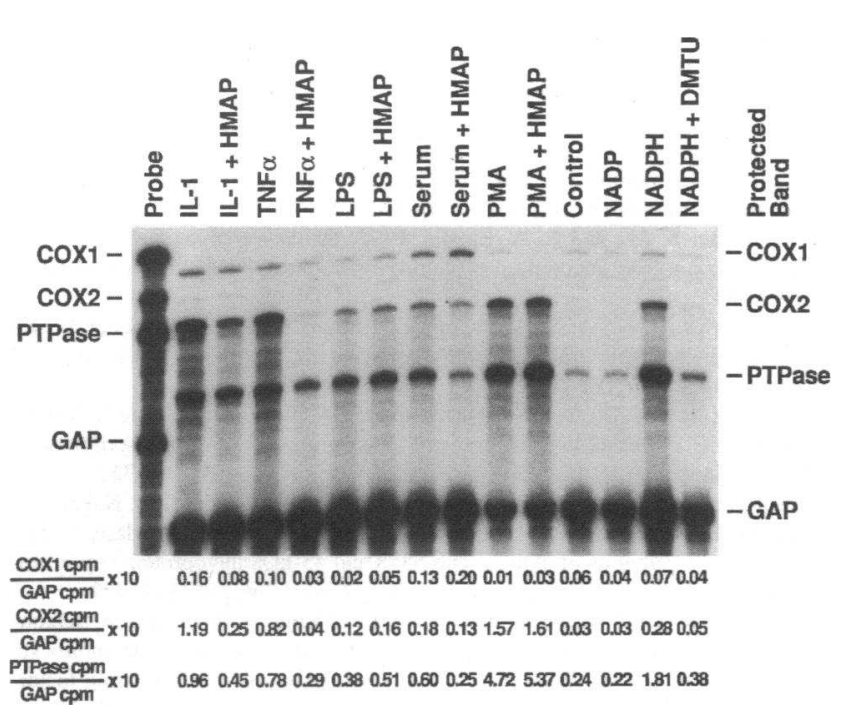

Figure 6. Effects of NADPH ( $5 \mathrm{mM})$ and HMAP $(100 \mu \mathrm{g} / \mathrm{ml})$ on COX-1, COX-2, and PTPase mRNA levels. Cells preincubated in serum-free medium for $48 \mathrm{~h}$ were further incubated with $10 \% \mathrm{FCS}$ medium or serum-free medium containing IL-1 ( $1 \mathrm{ng} / \mathrm{ml}), \mathrm{TNF} \alpha(200 \mathrm{U} / \mathrm{ml})$, LPS $(1 \mu \mathrm{g} / \mathrm{ml})$, or PMA (200 nM).

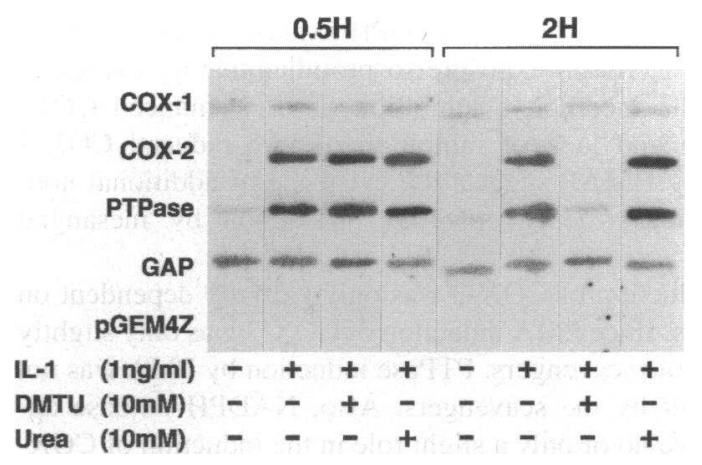

Figure 7. Effects of DMTU and TMTU urea on the transcriptional activity for COX-1, COX-2, and PTPase induced by IL-1, TNF $\alpha$, and LPS at $30 \mathrm{~min}$ and at $2 \mathrm{~h}$. Labeled transcripts $\left(10^{7} \mathrm{cpm} / \mathrm{ml}\right)$ generated by nuclei were hybridized with full-length cDNA for COX-1, COX-2, PTPase, GAPDH, and pGEM4Z (as a negative control).

by ROIs $(20,25)$. A homolog of IL- 8 in rats has not been identified; however, rat $\mathrm{KC}$ has some similarity with IL-8. In the current study, KC expression was not related to oxidant stress, since the scavengers had no effect on its expression (Fig. 4 ). Therefore, although both $\mathrm{COX}-2$ and $\mathrm{KC}$ gene expression are costimulated by IL-1, they are differentially inhibited by the scavengers. This observation further verified the specificity of the inhibitory effects of the scavengers on COX-2.

The observations that the addition of NADPH increased COX-2 expression and the NADPH oxidase inhibitor HMAP dramatically inhibited TNF $\alpha$-induced COX- 2 expression and partially inhibited IL-1 - and LPS-induced COX-2 expression indicate the involvement of NADPH oxidase in the generation of ROIs. However, several non-NADPH oxidase-dependent sources of ROI production also exist, including radicals generated during mitochondrial electron transport and arachidonate metabolism (26). Moreover, many cell types, such as endothe-

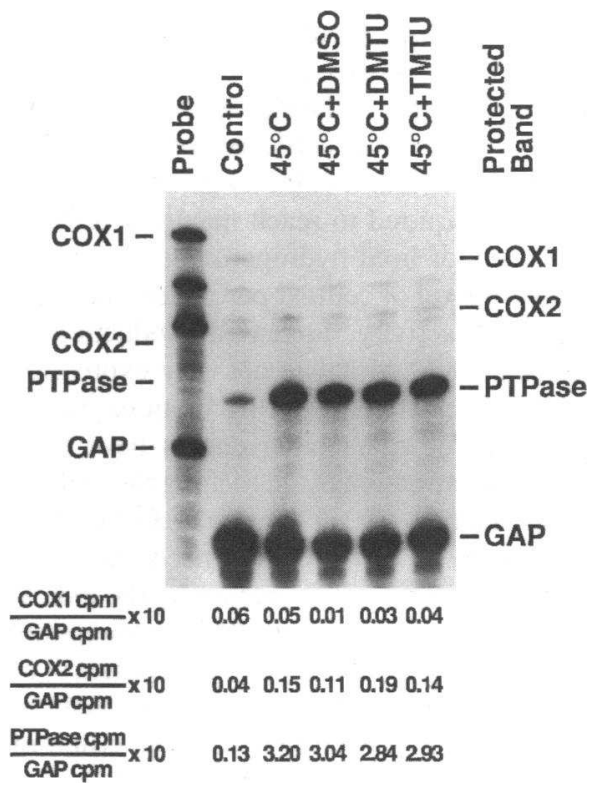

Figure 8. Effects of heat shock $\left(45^{\circ} \mathrm{C}, 5 \mathrm{~min}\right)$ on $\mathrm{COX}-1, \mathrm{COX}-2$, and PTPase mRNA levels, as assessed by RNase protection assay. The double bands result from incomplete digestion of the probes. 
lial cells and fibroblasts, lack NADPH oxidase systems, but can still produce ROIs on exposure to proinflammatory cytokines $(27,28)$. The incomplete inhibition of IL-1-induced COX2 expression and lack of inhibition of LPS-induced COX-2 expression by HMAP suggest the existence of additional nonNADPH oxidase-dependent ROI production by mesangial cells.

PMA induction of COX-2 was only partially dependent on oxidant stress, since PMA induction of COX-2 was only slightly inhibited by the scavengers. PTPase induction by PMA was not blocked at all by the scavengers. Also, NADPH oxidase appeared to have no or only a slight role in the induction of COX2 by PMA or serum, since there was no or little inhibition by HMAP of either, again suggesting that the PMA/serum signaling pathway of COX-2 expression differed from that of the ROIs.

In contrast to PTPase, heat shock stimuli failed to induce COX-2 expression. These observations suggest that COX-2 induction via ROIs is not just a general response to environmental or cytotoxic stress. Moreover, the differential induction of COX-2 and PTPase by heat shock suggests that the specific responses of these genes to the various stimuli represent different regulatory mechanisms. Indeed, heat shock-induced PTPase expression was not influenced by the scavengers DMTU and TMTU, whereas these scavengers were very potent inhibitors of cytokine-induced PTPase mRNA expression.

ROIs may serve as intracellular signals for gene activation involving specific transcription factors such as NK- $\kappa$ B (2933 ). Pyrrolidone-thiocarbamate has been shown to inhibit cytokine-induced activation of the NF- $\kappa$ B in several cell lines $(20$, 34,35 ). It did not effect cytokine-induced COX-2 expression in mesangial cells (data not shown). In addition, an NF- $\kappa \mathrm{B}-$ like element has not been identified in the promoter regions of rat or mouse genomic DNA, although it has been found in chicken inducible COX-2 (36-38). These observations suggest that $\mathrm{NK}-\kappa \mathrm{B}$ may not be involved in cytokine-induced/ROI scavenger-inhibited COX-2 expression.

The pathophysiologic significance of our finding that COX2 is an oxidant stress-inducible gene may help to explain the enhanced expression of COX-2 during inflammation. The ROIs produced by inflammatory cells could lead to the deleterious amplification of prostanoids during inflammation. Lipid hydroperoxides are important physiological activators of COX (12). An important aspect of COX is that it exhibits autoaccelerative reaction kinetics. The time required to reach maximal velocity is decreased in the presence of lipid hydroperoxides $(39,40)$. Thus, small increases in the level of cellular peroxides can cause dramatic increases in COX activity. Increased production of ROIs during inflammation could stimulate not only expression of COX-2, but also enzyme activity, resulting in an explosive production of prostanoids. The radical scavengers have been reported to block prostanoid formation by quenching the generation of hydroperoxides, which are the activators of COX (12). Our results suggest that such an interpretation needs to be reevaluated. The inhibition of prostanoid formation by the radical scavengers may be due to the suppression of COX-2 expression. The findings reported here suggest the potential efficacy of antioxidants in ameliorating inflammatory diseases not only to inhibit their direct effects, but also to aid in the suppression of prostanoids when desirable.

\section{Acknowledgments}

This is publication 8675-IMM from the Department of Immunology, The Scripps Research Institute, La Jolla, CA 92037. This work was supported in part by United States Public Health Service (USPHS) grant DK20043 by a grant from R. W. Johnson (C. B. Wilson), by USPHS grant DK41868, and by U.S. Department of Agriculture Competitive grant 93-37200-8961 (D. Hwang).

\section{References}

1. Xie, W., J. G. Chipman, D. L. Robertson, R. L. Erikson, and D. L. Simmons 1991. Expression of a mitogen-responsive gene encoding prostaglandin synthase is regulated by mRNA splicing. Proc. Natl. Acad. Sci. USA. 88:2692-2696.

2. Kujubu, D. A., B. S. Fletcher, B. C. Varnum, R. W. Lim, and H. R. Herschman. 1991. TIS 10, a phorbol ester tumor promoter-inducible mRNA from Swiss 3T3 cells, encodes a novel prostaglandin synthase/cyclooxygenase homologue. J. Biol. Chem. 266:12866-12872.

3. O'Banion, M. K., H. B. Sadowski, V. Winn, and D. A. Young. 1991. A serum- and glucocorticoid-regulated 4-kilobase mRNA encodes a cyclooxygenase-related protein. J. Biol. Chem. 266:23261-23267.

4. Hla, T., and K. Neilson. 1992. Human cyclooxygenase-2 cDNA. Proc. Natl. Acad. Sci. USA. 89:7384-7388.

5. Lee, S. H., E. Soyoola, P. Chanmugam, S. Hart, W. Sun, H. Zhong, S. Liou, D. Simmons, and D. Hwang. 1992. Selective expression of mitogen-inducible cyclooxygenase in macrophages stimulated with lipopolysaccharide. J. Biol. Chem. 267:25934-25938.

6. Pilbeam, C. C., H. Kawaguchi, Y. Hakeda, O. Voznesensky, C. B. Alander, and L. G. Raisz. 1993. Differential regulation of inducible and constitutive prostaglandin endoperoxide synthase in osteoblastic MC3T3-E1 cells. J. Biol. Chem. 268:25643-25649.

7. Pritchard, K. A., Jr., M. K. O’Banion, J. M. Miano, N. Vlasic, U. G. Bhatia, D. A. Young, and M. B. Stemerman. 1994. Induction of cyclooxygenase-2 in ra vascular smooth muscle cells in vitro and in vivo. J. Biol. Chem. 269:8504-8509.

8. Martin, M., D. Neumann, T. Hoff, K. Resch, D. L. DeWitt, and M. GoppeltStruebe. 1994. Interleukin-1-induced cyclooxygenase 2 expression is suppressed by cyclosporin A in rat mesangial cells. Kidney Int. 45:150-158.

9. Crofford, L. J., R. L. Wilder, A. P. Ristimäki, H. Sano, E. F. Remmers, H. R. Epps, and T. Hla. 1994. Cyclooxygenase-1 and -2 expression in rheumatoid synovial tissues. Effects of interleukin- $1 \beta$, phorbol ester, and corticosteroids. $J$. Clin. Invest. 93:1095-1101.

10. Feng, L., W. Sun, Y. Xia, W. W. Tang, P. Chanmugam, E. Soyoola, C. B. Wilson, and D. Hwang. 1993. Cloning two isoforms of rat cyclooxygenase differential regulation of their expression. Arch. Biochem. Biophys. 307:361-368.

11. Karayalcin, S. S., C. W. Sturbaum, J. T. Wachsman, J.-H. Cha, and D. W. Powell. 1990. Hydrogen peroxide stimulates rat colonic prostaglandin production and alters electrolyte transport. J. Clin. Invest. 86:60-68.

12. Lands, W. E. M., R. J. Kulmacy, and P. J. Marshall. 1984. Lipid peroxide actions in the regulation of prostaglandin biosynthesis. In Free Radicals in Biology. W. A. Pryor, editor. Academic Press, Inc., New York. 39-61.

13. Winrow, V. R., P. G. Winyard, C. J. Morris, and D. R. Blake. 1993. Free radicals in inflammation: second messengers and mediators of tissue destruction. Br. Med. Bull. 49:506-522.

14. Baud, L., Fouqueray, B., Philippe, C., and Ardaillou, R. 1992. Reactive oxygen species as glomerular autacoids. J. Am. Soc. Nephrol. 2(Suppl. 2):S132$\mathrm{S} 138$

15. Radeke, H. H., B. Meier, N. Topley, J. Floge, G. G. Habermehl, and K. Resch. 1990. Interleukin $1-\alpha$ and tumor necrosis factor- $\alpha$ induce oxygen radical production in mesangial cells. J. Clin. Invest. 37:767-775.

16. Keyse, S. M., and E. A. Emslie. 1992. Oxidative stress and heat shock induce a human gene encoding a protein-tyrosine phosphatase. Nature (Lond.). 359:644-647.

17. Charles, C. H., A. S. Abler, and L. F. Lau. 1992. cDNA sequence of a growth factor-inducible immediate early gene and characterization of its encoded protein. Oncogene. 7:187-190.

18. Feng, L., Y. Xia, J. I. Kreisberg, and C. B. Wilson. 1994. Interleukin-1 $\alpha$ stimulates KC synthesis in rat mesangial cells: glucocorticoids transcriptionally inhibit KC induction by IL-1. Am. J. Physiol. (Renal). 266:F713-F722.

19. Radeke, H. H., A. R. Cross, J. T. Hancock, O. T. G. Jones, M. Nakamura, V. Kaever, and K. Resch. 1991. Functional expression of NADPH oxidase components ( $\alpha$ - and $\beta$-subunits of cytochrome $b 558$ and $45-\mathrm{kDa}$ flavoprotein) by intrinsic human glomerular mesangial cells. J. Biol. Chem. 266:21025-21029.

20. Satriano, J. A., M. Shuldiner, K. Hora, Y. Xing, Z. Shan, and D. Schlondorff. 1993. Oxygen radicals as second messengers for expression of the monocyte chemoattractant protein, JE/MCP-1, and the monocyte colony-stimulating factor, CSF-1, in response to tumor necrosis factor- $\alpha$ and immunoglobulin G. Evidence for involvement of reduced nicotinamide adenine dinucleotide phosphate (NADPH)-dependent oxidase. J. Clin. Invest. 92:1564-1571.

21. Kreisberg, J. I., and M. A. Venkatachalam. 1986. Vasoactive agents affect mesangial cell adhesion. Am. J. Physiol. 251:C505-C511.

22. Xia, Y., L. Feng, T. Yoshimura, and C. B. Wilson. 1993. LPS-induced MCP-1, IL- $1 \beta$, and TNF $\alpha$ mRNA expression in isolated erythrocyte-perfused rat kidney. Am. J. Physiol. 264:F774-F780. 
23. Chomczynski, P., and N. Sacchi. 1987. Single-step method of RNA isolation by acid guanidinium thiocyanate-phenol-chloroform extraction. Anal. Biochem. 162:156-159.

24. Lanahan, A., J. B. Williams, L. K. Sanders, and D. Nathans. 1992. Growth factor-induced delayed early response genes. Mol. Cell. Biol. 12:3919-3929.

25. DeForge, L. E., A. M. Preston, E. Takeuchi, J. Kenney, L. A. Boxer, and D. G. Remick. 1993. Regulation of interleukin 8 gene expression by oxidant stress. J. Biol. Chem. 268:25568-25576.

26. Freeman, B. A., and J. D. Crapo. 1982. Free radicals and tissue injury. Lab. Invest. 47:412-426.

27. Matsubara, T., and M. Ziff. 1986. Increased superoxide anion release from human endothelial cells in response to cytokines. J. Immunol. 137:3295-3298.

28. Bautista, A. P., and J. J. Spitzer. 1990. Superoxide anion generation by in situ perfused rat liver: effect of in vivo endotoxin. Am. J. Physiol. 259:G907G912.

29. Schreck, R., P. Rieber, and P. A. Baeuerle. 1991. Reactive oxygen intermediates as apparently widely used messengers in the activation of the NF- $\kappa$ B transcription factor and HIV-1. EMBO (Eur. Mol. Biol. Org.) J. 10:2247-2258.

30. Toledano, M. B., and W. J. Leonard. 1991. Modulation of transcription factor NF- $\kappa \mathrm{B}$ binding activity by oxidation-reduction in vitro. Proc. Natl. Acad. Sci. USA. 88:4328-4332.

31. Henkel, T., T. Machleidt, I. Alkalay, M. Kronke, Y. Ben-Neriah, and P. A Baeuerle. 1993. Rapid proteolysis of I kappa B- $\alpha$ is necessary for activation of transcription factor NF- $\kappa$ B. Nature (Lond.). 365:182-185.

32. Schieven, G. L., J. M. Kirihara, D. E. Myers, J. A. Ledbetter, and F. M. Uckun. 1993. Reactive oxygen intermediates activate NF- $\kappa$ B in a tyrosine kinasedependent mechanism and in combination with vanadate activate the $p 56^{\mathrm{kt}}$ and p59 $9^{\mathrm{fyn}}$ tyrosine kinases in human leukocytes. Blood. 82:1212-1220.
33. Schenk, H., M. Klein, W. Erdbrügger, W. Dröge, and K. Schulze-Osthoff 1994. Distinct effects of thioredoxin and antioxidants on the activation of transcription factors NK-KB and AP-1. Proc. Natl. Acad. Sci. USA. 91:1672-1676.

34. Marui, N., M. K. Offermann, R. Swerlick, C. Kunsch, C. A. Rosen, M. Ahmad, R. W. Alexander, and R. M. Medford. 1993. Vascular cell adhesion molecule-1 (VCAM-1) gene transcription and expression are regulated through an antioxidant-sensitive mechanism in human vascular endothelial cells. $J$. Clin Invest. 92:1866-1874.

35. Xie, Q., Y. Kashiwabara, and C. Nathan. 1994. Role of transcription factor NF- $\kappa B / R e l$ in induction of nitric oxide synthase. J. Biol. Chem. 269:4705-4708.

36. Fletcher, B. S., D. A. Kujubu, D. M. Perrin, and H. R. Herschman. 1992 Structure of the mitogen-inducible TIS10 gene and demonstration that the TIS10 encoded protein is a functional prostaglandin G/H synthase. J. Biol. Chem 267:4338-4344.

37. Xie, W., J. R. Merrill, W. S. Bradshaw, and D. L. Simmons. 1993. Structural determination and promoter analysis of the chicken mitogen-inducible prostaglandin G/H synthase gene and genetic mapping of the murine homolog. Arch. Biochem. Biophys. 300:247-252.

38. Sirois, J., L. O. Levy, D. L. Simmons, and J. S. Richards. 1993. Characterization and hormonal regulation of the promoter of the rat prostaglandin endoperoxide synthase 2 gene in granulosa cells. Identification of functional and proteinbinding regions. J. Biol. Chem. 268:12199-12206.

39. Hemler, M. E., G. Graff, and W. E. M. Lands. 1978. Accelerative autoactivation of prostaglandin biosynthesis by $\mathrm{PGG}_{2}$. Biochem. Biophys. Res. Commun. 85:1325-1331.

40. Hemler, M. E., H. W. Cook, and W. E. M. Lands. 1979. Prostaglandin biosynthesis can be triggered by lipid peroxides. Arch. Biochem. Biophys. 193:340-345. 